This item was submitted to Loughborough's Research Repository by the author.

Items in Figshare are protected by copyright, with all rights reserved, unless otherwise indicated.

\title{
Employee tenure and the nationality of joint ventures in China
}

PLEASE CITE THE PUBLISHED VERSION

PUBLISHER

(C) Routledge (Taylor \& Francis)

VERSION

AM (Accepted Manuscript)

LICENCE

CC BY-NC-ND 4.0

REPOSITORY RECORD

Zimmermann, Angelika, Xiaohui Liu, and Trevor Buck. 2019. "Employee Tenure and the Nationality of Joint Ventures in China”. figshare. https://hdl.handle.net/2134/6473. 
This item was submitted to Loughborough's Institutional Repository (https://dspace.lboro.ac.uk/) by the author and is made available under the following Creative Commons Licence conditions.

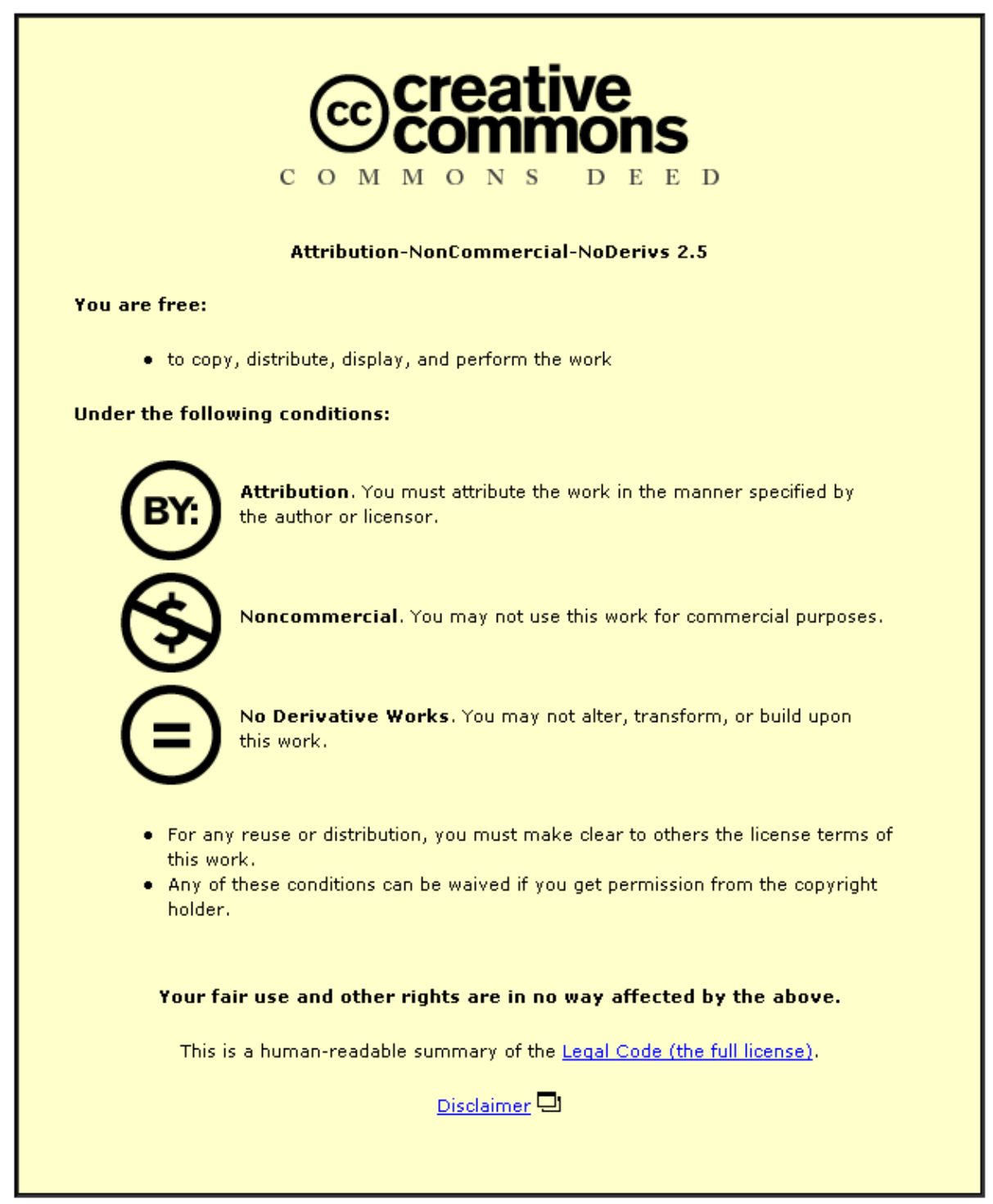

For the full text of this licence, please go to: http://creativecommons.org/licenses/by-nc-nd/2.5/ 


\title{
Employee Tenure in China and the Nationality of Joint Ventures
}

\begin{abstract}
The retention of qualified Chinese employees is an increasing concern for managers in China today. Various studies have highlighted the rise of turnover rates, and many have suggested how human resource practices can help promote retention. However, little research has compared employee tenure or the use of human resource practices for retention between firms of different nationality in China. From a theoretical point of view, such comparisons are likely to reveal differences, would be vital for gaining a better understanding of the phenomenon, and would help us in establishing best practice. We therefore conducted a comparison of average employee tenure and the use of HR practices between Sino-foreign joint ventures with Western (EU/US), overseas Chinese (Hong Kong/Taiwan), and other Asian (Japanese/Korean) partners. Primary data from questionnaire surveys were obtained from a total of 316 joint ventures in Beijing, Tianjin, and Qingdao. We found a significant relationship between nationality and tenure. Tenure was the highest in overseas Chinese, moderate in Japanese/Korean, and lowest in Western firms. The results also suggest that the variation in tenure between nationalities was partly mediated by the firms' use of a human resource practices. We discuss these results in terms of cultural differences and the long-term orientation of human resource systems.
\end{abstract}

\section{Keywords}

China; employee tenure; retention; human resource management, HRM practices; Sinoforeign joint ventures 


\section{Introduction}

For around half a century, the Chinese economy was dominated by state-owned enterprises (SOEs), employment stability and the notion of the 'iron rice bowl'. Since about 1990, however, gradual but deep economic reforms, including privatisation programmes, the liberalisation of new ventures and stock markets, have changed this situation drastically. Although some old-style SOEs remain, employee retention now constitutes a major concern of employers in China. How to attract Chinese talent and increase their tenure with the firm is a priority for managers in China, for human resource (HR) specialists as well as chief executives.

Employee turnover in China has risen continuously since the nineties and has increased even more dramatically since the end of the Asian crisis in 1998. According to Hewitt Associates, annual employee turnover across industries and cities rose from an average of $8.3 \%$ in 2001 to $14.7 \%$ in 2007 (Sheng and Earsdon 2007), and a Mercer study reported that the average tenure of 25- to 35-year-olds (the age group targeted by most multinational enterprises, MNEs) fell from around four years in 2004 to around two years in 2005 (Wilson 2006). This trend is likely to continue, as more foreign companies enter the Chinese market, existing firms expand, and the shortage of talent grows.

However, the problem may not be uniform for all companies in China. A few researchers suggest that Chinese and foreign firms experience retention problems to different degrees (Wang 2004; Rein 2007; Sovic 2006). Interestingly, we found only one study examining how tenure may vary across different types of foreign firm (Walsh and Zhu, 2007). Hence, there is surprisingly little theoretical or empirical research that draws this comparison.

We know even less about the reasons for Chinese employees to stay with firms of one nationality rather than another. Many best practice reports suggest that certain HR 
practices can serve to increase employee tenure in China (Goodall and Burgers, 1998; Melvin, 2001; Sheng and Earsdon, 2007; Speth and Doeringer, 2006). However, these reports do not compare firms of different nationality. Moreover, several academic studies have demonstrated that firms of different nationality vary in their use of HR practices in China (Farley, Hoenig, and Yang, 2004; Ngo, Turban, Lau, and Lui, 1998; Walsh and Zhu, 2007). However, these studies do not focus specifically on HR practices for retention.

In other words, both tenure and HR practices for retention have rarely been compared between firms of different nationality in China. This comparison is important, because it helps us to understand not only why Chinese employees stay with a firm or leave, but also how employee retention can be improved. Hence, we need to improve our theoretical understanding as well as our empirical basis concerning employee retention and HR practices for retention in different nationality firms in China

This paper takes the first step towards investigating whether employee tenure in China is bound up with foreign firm nationality. In particular, it asks whether different nationalities of foreign JV partners are associated with employee tenure and whether firms' HR practices are responsible for inter-firm variations in tenure. The findings from our research will contribute to a better understanding of the effectiveness of HR practices for retaining Chinese employees, and they generate important managerial implications for HR policies in China.

The paper is structured as follows. The following section reviews the literature on employee retention problems in China, including their foreign ownership dimensions. After this, we will describe HR practices in relation to job retention, again with a foreign ownership element. As a next step, we investigate why firms of different nationality are likely to vary in their HR practices and employee tenure. This leads to our hypotheses. We then present our methods, results, discussion, and conclusions. 


\section{Firm nationality and employee tenure}

Employee tenure and retention are here used synonymously, with tenure seen as the length of time that an employment post is occupied, and retention as keeping or holding employees in their posts, which implies tenure. In this section, employee retention in China is introduced, with distinctions between local and foreign-owned firms. A consideration of employee motives for staying with a firm leads to the subsequent section on HR practices for employee retention.

Most studies on staff retention in China do not distinguish between firms of different nationality. Some include Chinese as well as foreign firms, without comparing the two (Chen \& Francesco, 2000; Sheng and Earsdon, 2007; Wilson, 2006). Others examine retention in all kinds of foreign companies (Jackson \& Bak, 1998). However, a few papers make an exception. Walsh and Zhu (2007) compare different foreign companies (wholly owned firms as well as Sino-foreign JV's), including European, US, and Japanese. They find that turnover ranged from 1 per cent in a Sino-Japanese JV to 10 per cent in a SinoGerman JV. Moreover, evidence from practitioners suggests that highly qualified Chinese employees leave their foreign employers for better career prospects in Chinese firms. Western firms are highly attractive employers for young management candidates, because they provide training in Western management methods and often grant higher salaries. Nevertheless, Chinese firms may be regarded as more attractive employers in the long term. An early analysis by Chow et al. (1999) of manufacturing enterprises in Shanghai between 1989 and 1992 demonstrates higher turnover in foreign JVs as compared to Chinese SOEs. Sovic's (2006) anecdotal evidence further suggests that many MNEs lose their Chinese employees to local companies after a couple of years of training, because employees perceive that opportunities for career development and promotion are greater in Chinese firms. The same conclusions are reached by Rein (2007), who interviewed senior executives 
in MNEs. Their view was that many MNEs run into the pitfall of 'glass ceilings' for native Chinese. Senior ranks are commonly taken by Western or overseas Chinese expatriates. Two-tier pay systems often exist, with sometimes generous compensation packages for expatriates. In exit surveys, Chinese workers reported that the main reason they left was that they had no visible career paths.

One of the most interesting enquiries is by Wang (2004). He examines the organisational commitment of Chinese employees working in SOEs compared with foreigninvested enterprises (FIEs). Wang (2004) measures different types of organisational commitment, and most relevant for retention were active and passive continuance commitment. Passive continuance commitment describes an attachment due to necessity, where an individual stays with the organisation due to a lack of alternatives. Active continuance commitment describes the attachment of individuals to an organisation due to a feeling of individual achievement, such as awareness of an opportunity to improve oneself through promotion opportunities or on-the-job training. This attachment is seen as a reason for the employee to stay with the organisation. Interestingly, participants from SOEs scored higher on passive as well as active continuance commitment than employees in FIEs. The higher passive continuance commitment in SOEs is explained by government employment restrictions, making it difficult for workers to change place of residency without loosing social welfare benefits. In contrast, manual workers in FIEs are usually guest workers from other districts who do not expect residency anyway and therefore move easily from one FIE to another. The lower active continuance commitment found in FIE employees is seen as the result of an over-representation of elite employees in these firms. FIEs provide more training opportunities than SOEs. However, these are usually restricted to a small number of elite employees. In SOEs, most employees expect life-long employment and there may be long-term developmental opportunities available (Wang, 2004: 663). This implies that 
active continuance commitment would be higher for higher-level employees than manual workers in FIEs. In contrast, we argue that long-term career opportunities are limited for higher-level employees as well, given the mentioned 'glass ceiling' effect. Such barriers may have a negative effect on active continuance commitment and retention of higherskilled employees.

This difference in commitment depending on employees' skill level is investigated by Chen and Francesco (2000). They examine companies of unspecified nationality in China, and find that the higher position of Chinese employees is related to higher organisational commitment. They attribute this finding not to career opportunities, but to a cultural factor. Employees in higher positions will have stronger guanxi, i.e. personal relationships with influential people such as the boss, which were necessary to come to this position. The guanxi relationship is seen to create a stabilising effect and increase the commitment to the organisation that the boss represents. In our view, stronger guanxi would then be another reason why higher skilled employees have better career chances. However, even if career chances, commitment, and retention are greater in higher than in lower level employees, it is the turnover of higher skilled employees that presents the most pressing issue.

A number of relevant conclusions can be drawn from these studies. Retention of Chinese employees may be a greater problem for FIEs than for Chinese firms. For all levels of employees, this may be due to better long-term development opportunities in Chinese firms. Higher level employees may in addition stay with the firm due to the strong guanxi that brought them into this position. Retention comparisons have so far focused on Chinese firms in contrast to FIEs as a whole. Most research does not examine whether retention problems vary with the nationality of the foreign investor. Before demonstrating why such a 
comparison is worthwhile, we now have a closer look at the HR practices that may promote retention.

\section{HR practices for employee retention}

There are abundant suggestions regarding the HR practices that should be deployed to gain an advantage over competitors in attracting and retaining key employees (e.g., Goodall and Burgers, 1998; Jackson and Bak, 1998; Melvin, 2001; Speth and Doeringer, 2006). Consultancies such as Hewitt, Mercer, and Watson Wyatt worldwide conduct regular surveys to capture the latest developments. Best practices are collected from firms with outstanding retention figures, and best practice employers are identified by a Hewitt study each year.

The reviewed influences on Chinese employees' continuance commitment point to the importance of certain HR practices for achieving a higher tenure of Chinese employees. Long-term career chances and social welfare are designed by human resource management (HRM) specialists. Interestingly, recent research on HRM in China converges in the view that career prospects have become just as relevant as financial incentives for retaining Chinese employees. This corresponds to the observations regarding the effect of career barriers, and it accords with Wang's (2004) explanation for higher active continuance commitment in SOEs. Personal relationships, particularly that with one's boss are also frequently mentioned. This accords with Chen and Francesco's (2000) view that guanxi is important for higher level employees' intention to leave or stay with a company. Social benefits are another recommended retention tool.

To illustrate, Goodall and Burgers (1998) conduct a survey of 80 experienced Chinese managers. A greater number of respondents cited 'soft' factors' as reasons to stay or leave, such as job-development opportunities and interpersonal relationships, compared to 'hard factors', including salaries. In a Watson Wyatt international survey in 2005, 
monetary benefits as well as career prospects and development were the most important reasons for staying or leaving, besides job stability and security (The China Business Review, 2006). Mercer Human Resource consulting conducted a survey of 114 organisations in Greater China in 2005 (Wilson, 2006). The most highly rated methods of attracting and retaining staff were 'attractive salary and benefits package' (23\% of respondents), and 'opportunities for career development (19\%). On the basis of this study, Malila (2007) suggests that firms have to adopt a more long-term, strategic approach to HRM. They should 'build, not just buy' their workforce through training, career development and pay for performance, in order to make it sustainable. Upward mobility has to be ensured for talented PRC nationals. Melvin (2001) draws on a Korn Ferry survey in 2001 and stresses that career development plans are key retention tools. The Korn Ferry research also identified relationships with one's boss as a crucial motivating factor, second behind career development and even before salary.

Many recommendations have been given regarding the other main retention tool, financial incentives. Melvin (2001) provides a useful summary, stating that salaries remain the basis of comparison between different job offers, but need to be combined with many other tangible and intangible retention techniques in order to be effective in the increasingly sophisticated Chinese job market. These can include performance-related bonuses and stock options, 'golden handcuffs', which are financial incentives for staying with the firm for a contractually specified amount of time, or 'iron handcuffs', which are punitive fines for leaving the firm before the end of one's contract.

Melvin (2001) further outlines social benefits used as retention tools, which are government-mandated payments into the government-run social insurance funds. These funds include housing, pension, medical, unemployment, accident/disability and maternity. Of these, pension funds place the largest burden on employers. Benefits are also given in 
terms of assistance with mortgages and housing, additional accident and medical assistance, child care, extra holiday time, amongst many others. However, the effectiveness of social benefits for retaining Chinese staff has been questioned. Zheng, Morrison, and O'Neill (2006) demonstrated that HRM practices in Chinese SMEs could help achieve better HRM outcomes, including lower levels of staff turnover and higher levels of staff commitment. Nevertheless, the 'Social Benefit' factor, which included the provision of social security schemes, was negatively related to retention. This was seen to be consistent with the findings from earlier research of Chinese enterprises, where the provision of social benefits was associated with the old regime and was not thought to be a beneficial element in performance management (see Goodall and Warner, 1999).

The most effective retention tools for top talent in China may have to be differentiated with regard to employees' years of service and age. Hewitt associates found in 2005 that for the age groups of 25-30 as well as 30-40, career opportunities, education reimbursement, and housing benefits were amongst the most important (Speth and Doeringer, 2006). The younger group additionally valued training, whilst the 30-40 year olds sought exposure to senior management. For the $40+$ age group, different incentives were important, namely retirement benefits, medical benefits, long-term incentives, work/life balance, and external recognition. This takes Wang's (2004) suggestions regarding the reasons for continuance commitment a step further. Whilst career and development opportunities are likely to be more important for younger employees, older employees may be retained to a larger extent by social benefits. In the same vein, Melvin (2001) suggests that employment packages in China are more competitive if they are tailored, for example to employees' age, gender, position, and personality. As with retention figures, HR practices for retention have not directly been compared between firms of different nationality in China. 


\section{Nationality, employee tenure, and HR practices}

We have so far demonstrated that Chinese and foreign firms may encounter retention problems to different degrees, and outlined HR practices that may promote retention. Both tenure and HR practices have rarely been compared between firms of different foreign nationality in China. We argue that such a comparison should be conducted, because different nationalities are likely to experience retention problems to different degrees. Firstly, they may differ in their use of HR practices that help them achieve higher retention. Such HR practices are likely to be influenced by the firm's cultural, institutional, and historical background. Secondly, retention problems may depend on the firm's language, and, thirdly, on their country's relationship with the PR of China.

It should be noted that HR practices of foreign firms in China are usually partly adapted to the Chinese context, and therefore only partly congruent with the practices used in the foreign home country (Ngo et al., 1998; Walsh and Zhu, 2007). Moreover, in Sinoforeign JVs, the Chinese partner tends to have a significant influence on HR practices (Goodall and Warner, 1997; Walsh and Zhu, 2007). Nevertheless, the influence of the foreign partner is likely to be discernible. Bjorkman and $\mathrm{Lu}$ (2001) demonstrate that HRM in JV's were determined more by the foreign than the Chinese partner. Accordingly, Zhu and Warner (2004) find that the greater the degree of foreign ownership, the more likely it was that formal HR practices were adopted.

This suggests that HR practices in JVs vary with the nationality of the foreign parent firm. A number of studies support this view, by comparing Japanese, US American and other Western firms. Walsh and Zhu (2007:265) found differences between firms of Japanese, US, and European (whole or partial) ownership in China. For example, US firms were more likely to have individual-based pay, larger internal wage disparities, and less permanent employment contracts than Japanese firms. In Farley et al.'s (2004) enquiry, US 
firms were more likely to use merit-based employment, and Japanese firms were more likely to offer lifetime employment. In the same vein, Ngo et al. (1998) compare companies in Hong Kong, and demonstrate greater similarities between Asian (Singaporean, Hong Kong Chinese and Japanese) firms and between Western (British and US) firms, than between Western and Asian firms.

‘Asian' as opposed to 'Western' HRM is also distinguished by Rowley, Benson, and Warner (2004). They identify a partial convergence of HRM in China, Japan, and South Korea. It is shown that HRM in each of these countries converged on parts of the Western HRM model in terms of flexible sourcing, unionism, and performance-based remuneration. Nevertheless, HRM in the three countries is still distinct from HRM in the West. Generally speaking, these nationalities still seem to adhere more than Western firms to traditional, long-term HR strategies in terms of secure promotion, long-term employment and predictable promotion. Zhu, Warner, and Rowley (2007) investigate HRM in the same countries and, additionally, Taiwan, Malaysia, Thailand, and Vietnam. They demonstrate that all these Asian countries retain traditional, group-oriented HRM characteristics.

The question now arises which HR practices suit the Chinese context better and are more likely to be accepted by Chinese employees. Which practices lead to better outcomes, in particular employee retention? With regard to Western HRM, Bjorkmann and Xiucheng (2002) suggest that some Western 'high-performance HRM practices' are less effective in China than in Western countries. Such limited success of Western HR practices is sometimes attributed to cultural differences. Asian firms in turn may benefit from their cultural proximity to China. In particular, Japanese, Korean, Chinese, and overseas Chinese (Hong Kong and Taiwan) citizens share parts of their cultural and historical heritage. For example, Confucianism has shaped societal structures and values in these countries, and the countries score similarly on various cultural value indexes. On the Hofstede (2003) scale, 
they all obtain high values for long-term orientation (LTO: the degree to which a society embraces long-term devotion to forward thinking values), power distance and collectivism. Asian HR professionals may for these reasons be in a better position than their Western counterparts to understand Chinese employees' expectations, and to design HR practices accordingly.

Some researchers use cultural proximity explicitly to explain the degree of HRM effectiveness in China. For example, Jackson and Bak (1998) argue that Western reward systems do not sufficiently take into account Chinese collectivistic attitudes, and certain incentives, such as housing benefits, should be used to promote loyalty and belonging. On a personal level, cultural proximity may motivate Chinese employees to build stronger guanxi with Asian than with Western colleagues and superiors, which may then be an incentive to stay with the firm (Chen and Francesco, 2004). Cultural proximity to China appears to be particularly high for overseas Chinese nationals. Ngo et al. (1998) find important differences between Japanese and Hong Kong/Singaporean Chinese companies in Hong Kong. For example, Chinese firms provided training that was more effective in increasing employee retention than that provided by Japanese firms. They conclude that researchers should distinguish between HR practices in Japanese and Hong Kong/Singaporean firms.

There are, however, some findings that contradict this cultural proximity view. Chinese employees may expect and accept Western management practices from their Western employers, and may even prefer them to Asian practices. For example, Selmer (1996) demonstrate that subordinate managers assessed the leadership behaviour of their Western expatriate bosses to be significantly closer to that of their perceived ideal boss, with American leadership behaviour being the most preferred and Japanese leader style the least preferred. Moreover, the HR practices that Asian firms apply in China may not be highly effective. For example, Taura (2005) observes that Japanese firms in China offer lower 
wages and less career advancement than their Western counterparts. Legewie (2002) posits that the Japanese, heavily expatriate-based system causes a 'them-we' mentality. This may create a perceived limitation for the career of Chinese employees. It is thus ambiguous whether Western or Asian firms deploy more effective HR practices in China. This makes it less certain which nationalities are likely to face greater retention difficulties.

This ambiguity regarding retention difficulties is reinforced when considering the role of language. Language difficulties for Chinese employees will be greater with some foreign firms than others. Overseas Chinese firms will be the least threatening in terms of language requirements, followed by Western organisations that use English. Japanese firms, in contrast, often maintain Japanese as the company language, which makes a career for Chinese staff in these firms very difficult (Taura, 2005). This language factor therefore supports a distinction between overseas Chinese and other Asian firms. Moreover, acquiring English language skills may be seen as an opportunity for career development. Walsh and Zhu (2007) report that employees were leaving a Sino-Japanese JV for new career development opportunities at European and American companies. These were viewed as more attractive partly because they provided 'the opportunity for employees to develop English language skills' (p. 256).

Finally, historical relationships with other countries could cause Chinese employees to feel either more or less affectively committed to employers of different nationality. It is uncertain how attractive Japanese companies are as employers, given the political and historical resentments some Chinese hold against Japan as a country. Western countries may be attractive due to the fashion of absorbing 'everything Western', whilst overseas Chinese firms may be attractive due to the common cultural grounds they share with their Chinese employees. 
These cross-national comparisons illustrate that retention and HR practices may vary with the nationality of a foreign firm in China. The direction of these differences is, however, not clear-cut and is not apparent from the literature. The reviewed literature also suggests that differences in HR practices may be bound to certain nationality clusters, namely Western in contrast to Japanese and Korean, and both in comparison to overseas Chinese firms.

For our investigation, we therefore distinguished between three nationality clusters in relation to HRM and employee tenure in Sino-foreign JVs: (1) Western (EU and US), (2) overseas Chinese (Hong Kong and Taiwanese), and (3) other Asian (Japanese and Korean) nationality. We examined three hypotheses based on our literature review above:

- Hypothesis 1: Different nationalities of foreign partner (a. Western, b. Overseas Chinese, c. Japanese and Korean) are associated with significantly different levels of employee tenure in Sino-foreign JVs.

- Hypothesis 2: Different nationalities of foreign partner are associated with significantly different HR practices in Sino-foreign JVs.

- Hypothesis 3: The HR practices adopted by Sino-foreign JVs are significantly related to employee tenure.

\section{Methods}

\section{Sample}

We focused on employee tenure and HR practices in Sino-foreign JVs with three categories of foreign partner (a. Western, b. Overseas Chinese, c. Japanese and Korean). In these JVs, the nationality of foreign partners represents a different degree of LTO or cultural proximity. Nationality of foreign partner was the main explanatory variable together with HR practices, which were also dependent variables in the context of $\mathrm{H} 2$. 
The paper is based empirically on a postal questionnaire survey conducted during 2006 with 316 Chinese-foreign JVs, where questions related to the period 1998-2005, since in 1998 foreign ownership shares in JVs were freed from State controls. We limited the sample to high-tech industries in order to control for the impact of industrial affiliation on HR practices and employee tenure across the three types of foreign JVs. Three cities, Beijing, Tianjin and Qingdao, were surveyed because of their domination of the foreign JV sector in China. In particular, Japanese, Korean and Chinese JVs mainly locate in the Pan Bohai region where these three cities accounted for $67 \%$ of Korean and $40 \%$ of Japanese investment in China (Wang, 1998). Selecting our sample firms from the three cities enabled us to avoid the problem of the under-representation of Sino-Korean JVs in other regions. According to lists obtained from the Beijing, Tianjin and Qingdao Industry and Commerce Bureaus, in 2006 there were 2,126 foreign JVs in Beijing, 1,075 in Tianjin and 461 in Qingdao. Each foreign JV was approached and a willingness to participate in our survey was indicated by $2,053 \mathrm{JIVs}$, representing $53 \%$ of the foreign JV population in these three cities.

Our survey instrument was translated from English into Mandarin Chinese and then back-translated by three Chinese professors in Beijing, to ensure its validity. A pilot study was carried out where two workshops were organized, involving groups of 6 and 8 senior managers of three types of Sino-foreign JVs. They were asked to complete the questionnaire and identify ambiguous questions. We modified the questionnaire accordingly, based on the feedback received from the workshops and copies were mailed to the 2,053 JVs.

A total of 316 useable questionnaires were obtained (a response rate of 15\%) with 104 JVs with US-EU partners; 103 with overseas Chinese ownership (Hong Kong and Taiwan); and 109 with other Asian co-owners (Japan and Korea). The possibility of nonresponse bias was checked by comparing the characteristics of the respondents with those of 
the population. The calculated t-statistics for the number of employees, local Chinese ownership and age of the firm were all statistically insignificant, indicating no significant differences between respondent and non-respondent firms. One questionnaire was completed in each firm by the CEO or senior managers. A broad overview of tenure and HR practices across employee groups was gained by relating the questions to all professional levels and age groups.

\section{Measures}

An overview of the research variables is provided in Figure 1. This figure also demonstrates the examined relationships between variables.

- Figure 1 about here -

The nationality of the foreign partner was assessed by asking for 'the national origins of the JV parent firm(s)'. Current ownership stakes in the JV were requested in terms of the percentage of investment by the Chinese partner and by the foreign partner. Employee tenure was assessed in terms of 'What is your average employee's tenure with the firm?' followed by a choice between the categories (1) '<1 year', (2) '1-3 years', (3) '4-5 years', (4) ‘6-10 years', and (5) 'over 10 years'.

We assessed a number of HR practices relevant to employee retention. Career prospects and development opportunities were captured firstly by questions on the numbers of foreign versus local managers, assuming that this reflects the career opportunities for Chinese employees (the existence of a 'glass ceiling'). Participants were asked to indicate 'the percentage of expatriates in total employees' and 'the percentage of local managers in total employees'. Secondly, the length of an employee's contract with the firm is likely to reflect the firm's intention to retain an employee and give them a chance for long-term development. We thus inquired 'What is the percentage of employees who have signed a contract for over 5 years?' As a financial incentive, the bonus system was investigated, in 
terms of the time periods for which bonuses were allocated: 'Are employee bonuses paid according to firm/employee performance over (1) weeks, (2) months, (3) quarters, or (4) one year'. As an important part of social benefits, we asked for the 'Average contribution of the JV to employees' pension fund (as a percentage of total pay'). To observe participant's attitudes towards pensions, we also asked them to rate the extent to which they agreed with the statement 'Pension provision is the responsibility of the company towards employees', on a scale from one (=low extent) to seven (=high extent). This measure reflects primarily the attitude of the individual participant. It can, however, correspond to the company culture.

\section{Control variables}

A question on the recent increase of workforce served to examine whether employee tenure was independent of the company's growth in the number of employees in recent years: 'In any single year of the last seven years, what was the largest percentage of labour force increase?'. To examine whether differences in tenure might be due to a variation in the age of the company, we asked 'How many years has the company been established?'.

\section{Results}

Chi square $(\chi 2)$ analysis was conducted to examine relationships between categorical variables, and univariate analysis of variance (ANOVA) was used for continuous independent variables. Some of the Chi square tests required merging different answer categories, namely when the amount of answers for more than $20 \%$ of the cells in the Chi matrix were too low (i.e., had an expected count of less than five). For example regarding average tenure, the number of responses in the categories ' $<1$ year' and ' $1-3$ years' were small, and the categories were merged into a category of ' $0-3$ years'. Four sets of relationships were examined to test our three hypotheses: (H1) the relationship between the nationality of the foreign partner and employee tenure; (H2) between nationality of the 
foreign partner and HR practices; and, (H3) between HR practices and employee tenure. The significance levels of these tests are provided in Table 1 . We also tested the interrelationships between HR practices which were implicitly embedded in our hypotheses. These are shown in Table 2.

- Table 1 and 2 about here -

\section{Nationality and tenure (H1)}

H1 was confirmed. We found significant differences in employee tenure between the JVs with different nationalities of foreign partner $\left(\chi^{2}=13.89\right.$; $\mathrm{df}=6$; Asymp. Sig. (two-sided) $=$ 0.031). Figure 2 illustrates the tenure differences between the different nationality clusters (in terms of the means of chosen category numbers). Tenure was significantly higher in the overseas Chinese firms (Mean $=3.15 ; \mathrm{N}=103 ; \mathrm{sd}=0.96)$ compared to Japanese and Korean firms $($ Mean $=3.05 ; \mathrm{N}=109 ; \mathrm{sd}=0.985)$, which in turn scored higher than Western firms (Mean $=2.72 ; \mathrm{N}=104 ; \mathrm{sd}=0.99)$. Relatedly, counts of employee tenure are provided

in Figure 3. The distribution of counts across the answer categories was significantly different for each nationality. EU/US participants had a greater skew towards the category of 0 to 3 years of tenure, with overall 53 responses in this category compared to 37 for Japanese/Korea and 30 in overseas Chinese firms. Japanese/Korean companies had the highest count in the middle category (4-5 years), whilst overseas Chinese had the greatest count in the higher category of 6-10 years, counting 33 responses compared to only 17 from the Western and 26 in the Japan/Korea firms. The numbers for the highest tenure $(>10$ years) were small for all nationalities, with Japan/Korea counting the highest.

- Figure 2 and 3 about here -

We controlled for two potential intervening variables, age of the company and recent growth. The assumption was that higher tenure could be positively associated with the older age of firms or the recent employment growth of a company. The age variable on its own 
was significantly related to tenure (ANOVA: $\mathrm{df}=5 ; \mathrm{F}=24$; Sig. $=0.000$ ), whilst growth was not significantly related to tenure $(\chi 2=8.9 ; \mathrm{df}=6$; Symp. Sig $(2 \operatorname{sided})=0.177)$. We subsequently used analysis of covariance (ANCOVA) to assess the relationship between nationality and tenure after controlling for firm age and growth. ANCOVA required us to create continuous numbers from the categorical tenure measures, which was achieved by taking the means of each tenure category as an actual number. For example, the category ' $<$ 1 year' was substituted by its mean: ' 0.5 '. This procedure leads to exaggerated differences between scores, because scores located near the borderline of a category are also counted as if they were in the mean of the category. However, this would affect all variables in the test, and the control method would therefore still be valid. The relationship between nationality and tenure was still significant when controlling for age $(\mathrm{df}=2 ; \mathrm{F}=6.4$; Sig. $=0.002)$ and growth $(\mathrm{df}=2 ; \mathrm{F}=4.3$; Sig. $=0.014)$. These results are consistent with H1.

\section{Nationality, HR practices, and tenure $(\mathrm{H} 2, \mathrm{H} 3)$}

There were mixed results regarding both $\mathrm{H} 2$ and $\mathrm{H} 3$. Both hypotheses were only partly confirmed. In relation to $\mathrm{H} 2$, we first report on the $\mathrm{HR}$ practices that were significantly related to national origin of the foreign JV partner. This includes the number of local versus foreign staff, the proportion of long-term contracts, and average contributions to pension funds. We then report on the HR practices that were not significantly related to nationality,

namely pension responsibility and type of bonus. To examine H3, we state whether each HR practice was significantly related to employee tenure or not.

A highly significant difference between firms of different nationality was found regarding the amount of local and foreign staff, namely 'the percentage of expatriates in total employees' (ANOVA: $\mathrm{df}=2 ; \mathrm{F}=9.77$; Sig. $=0.000$ ) and 'the percentage of local managers in total employees' (ANOVA: $\mathrm{df}=2 ; \mathrm{F}=7.4$; Sig. $=0.001$ ). Overseas Chinese firms had the lowest percentage of foreign expatriates $($ Mean $=3.75 ; \mathrm{N}=103$, $\mathrm{sd}=3.99$ ), 
whilst Japanese/Korean firms were in the middle (Mean $=6.45 ; \mathrm{N}=109 ; \mathrm{sd}=5.39)$ and EU/US companies scored the highest $($ Mean $=6.69 ; \mathrm{N}=104 ; \mathrm{sd}=6.31)$. The pattern for local staff was, however, not the converse. With regard to percentages of local managers, Western firms again scored the highest $($ Mean $=14.48 ; \mathrm{N}=104 ; \mathrm{sd}=7.73)$ followed closely by overseas Chinese firms $($ Mean $=13.44 ; \mathrm{N}=103 ; \mathrm{sd}=8.03)$. Japanese/Korean firms employed the smallest percentage of local managers $($ Mean $=10.52 ; \mathrm{N}=109 ; \mathrm{sd}=7.61)$. Overall, Japanese/Korean firms seemed to be the least localised, given their low percentages of local managers and high number of expatriates. Overseas Chinese firms appeared to employ the least expatriates. Western firms, interestingly, scored highest both with regard to local and foreign employees. Contrary to our expectations (H2), the degree of localisation, in terms of local versus foreign staff, was not significantly related to employee tenure (see Table 1).

We found a significant difference between nationalities regarding the percentage of employees who had signed a contract for over 5 years $(\chi 2=21.47$; $\mathrm{df}=8$; Asymp. Sig. (2sided $=0.006$ ). Overall, overseas Chinese had the highest percentage of long-term contracts $($ Mean $=3.81 ; \mathrm{N}=103 ; \mathrm{sd}=1.65)$, followed by Japan/Korea $($ Mean $=3.54 ; \mathrm{N}=109 ; \mathrm{sd}=$ 1.57) and then EU/US (Mean = 3.26; $\mathrm{N}=104 ; \mathrm{sd}=1.69$ ). The most striking difference was with regard to the highest percentage, that is, the category of $>30 \%$ of employees who signed an over five year contract. Overseas Chinese scored highest on this category $(\mathrm{N}=$ 59), followed by Japan/Korea $(\mathrm{N}=48)$ and then the EU/US $(\mathrm{N}=39)$. Conversely, EU/US scored highest on the lowest percentage of employees with long-term contracts $(\mathrm{N}=31$; compared to $\mathrm{N}=23$ for overseas Chinese and $\mathrm{N}=19$ for Japan/Korea). Japan/Korea scored highest on the middle, $6-10 \%$, category $(\mathrm{N}=14$, compared to $\mathrm{N}=5$ for Western and $\mathrm{N}=2$ for overseas Chinese). The long-term contract variable was highly significantly related to 
employee tenure $\left(\chi^{2}=214.1 ; \mathrm{df}=9\right.$; Asymp. Sig. $(2$-sided $\left.)=0.000\right)$, with a virtually linear relationship.

A firm's average contribution to employees' pension funds was significantly related to nationality at the border level of $p=0.05\left(\chi^{2}=9.47\right.$; $\mathrm{df}=4$; Asymp. Sig. (2-sided $)=$ 0.05). Western and Japanese/Korean firms had similar averages and patterns of pension contributions $($ Mean $=2.19 ; \mathrm{N}=104 ; \mathrm{sd}=0.90$ for Western and Mean $=2.21 ; \mathrm{N}=109 ; \mathrm{sd}=$ 0.92 for Japanese/Korean firms), but overseas Chinese firms had a skew towards the highest category of pension funds, and a higher average contribution $($ Mean $=2.49 ; \mathrm{N}=103 ; \mathrm{sd}=$ 0.78). The contributions to pension funds were highly significantly related to employee tenure $\left(\chi^{2}=34.77 ; \mathrm{df}=6\right.$; Asymp. Sig. $(2$-sided $\left.)=0.000\right)$, again in a virtually linear relationship.

Attitudes towards the firm's responsibility for pension provision was not significantly related to nationality, but was significantly related to tenure (ANOVA: $\mathrm{df}=6$; $\mathrm{F}=2.234$; Sig. $=0.049)$. The pattern of relationship was again approximately linear.

The type of bonus was not significantly related to either nationality $(\chi 2=5.73 ; \mathrm{df}=$ 4; Asymp. Sig. $(2$-sided $)=0.22)$ or tenure, although the relationship with tenure came close to the significance level $(\chi 2=12.172 ; \mathrm{df}=6$; Asymp. Sig. $(2$-sided $)=0.058)$. However, the pattern of relationship with tenure was counterintuitive and not linear. Short-term bonuses (i.e. the collapsed categories of 'weekly' and 'monthly' bonuses) were related to the highest tenure $($ Mean $=2.1 ; \mathrm{N}=210 ; \mathrm{sd}=0.94)$, yearly bonuses to the second highest tenure (Mean $=1.62 ; \mathrm{N}=32 ; \mathrm{sd}=0.75)$, and quarterly bonuses to the third highest tenure $(\mathrm{Mean}=1.86$; $\mathrm{N}=72 ; \mathrm{sd}=0.98)$.

\section{Interrelationships between HR practices}

The clustering of HR practices is summarised in Table 2. It can be seen that the association between percentage of expatriates and local managers was non-significant, which 
corresponds to the finding that Western firms had high levels of both expatriates and local managers. In contrast, there were interrelations between all other HR variables, namely, long-term contracts, contribution to pension funds, pension responsibility, and bonus types. Hence, the amount of long-term contracts was significantly associated with the average contribution to pension funds $(\chi 2=22.72 ; \mathrm{df}=8$; Asymp. Sig. $(2$-sided $)=0.004)$ and pension responsibility $\left(\chi^{2}=24.66 ; \mathrm{df}=12\right.$; Asymp. Sig. $(2$-sided $\left.)=0.017\right)$. These relationships were approximately linear. As may be expected, the two variables for responsibility of pension provision and for contribution to pension funds were significantly and linearly related to each other (ANOVA: $\mathrm{df}=4 ; \mathrm{F}=9.537$; Sig. $=0.000)$, indicating that the respondents' views on responsibilities accord with the firms' policies regarding pension funds.

The type of bonus was also significantly related to each of these other HR practices, namely long-term contracts $(\chi 2=14.43 ; \mathrm{df}=6$; Asymp. Sig. $(2$-sided $)=0.025)$, contribution to pension funds $(\chi 2=11.8 ; \mathrm{df}=4$; Asymp. Sig. $(2$-sided $)=0.019)$, and pension responsibility $\left(\chi^{2}=17.18 ;\right.$ df $=8$; Asymp. Sig. $(2$-sided $\left.)=0.028\right)$. However, these relationships were counterintuitive and not linear. Quarterly bonuses were associated with the lowest scores on each of these other HR practices. The combined category of weekly and monthly bonuses was associated with the highest scores for long-term contracts and contributions to pension funds, and yearly bonuses with the second highest. In contrast, yearly bonuses were related to the strongest agreement with pension provision being the responsibility of the company, and weekly/monthly bonuses to the second highest.

We also found significant associations between the percentage of local managers and the firm's contribution to pension funds (ANOVA: df =4; F = 3.4; Sig. $=0.008$ ); and with type of bonus (ANOVA: $\mathrm{df}=3 ; \mathrm{F}=2.63$; Sig. $=0.05$ ), both with a close-to-linear relationship. All other relationships between the HR variables were not significant. 


\section{Implications of results}

As predicted in $\mathrm{H} 1$, the nationality of JV partners was significant in relation to average employee tenure. Tenure was the highest in overseas Chinese, moderate in Japanese/Korean, and lowest in Western firms. Some of our results suggest that this variation in tenure may be mediated by the firms' use of particular HR practices.

Two of the six measured HR practices were significantly related to both nationality and tenure, which partly confirms $\mathrm{H} 2$ as well as $\mathrm{H} 3$. These statistically significant practices were the award of long contracts and employers' pension contributions. In contrast, four HR practices did not seem to be associated with tenure differences, because these HR practices did not relate to both tenure and nationality. Two HR practices were related only to nationality (confirming $\mathrm{H} 2$ but not $\mathrm{H} 3$ ), one only to tenure (confirming $\mathrm{H} 3$ but not $\mathrm{H} 2$ ), and one to neither nationality nor tenure (refuting $\mathrm{H} 2$ and $\mathrm{H} 3$ ). The percentage of expatriates and the percentage of local managers varied between JVs with different nationality, but were not related to employee tenure. Conversely, the perceived responsibility to provide pension funds was related to differences in tenure, but not to nationality. The type of bonus system did not vary significantly with either nationality or tenure, although the relationship with tenure came only close to significance $(\mathrm{Sig} .=0.058)$. We now first discuss the findings that supported our hypotheses, and then turn to the unexpected results.

The relationship of long-term contracts with nationality is in certain respects counter-intuitive. If employee tenure is a great challenge for firms in China, then firms of all nationalities should be eager to offer their employees long-tem contracts. It therefore seems to be a contradiction that Western firms in our survey did not sign as many long-term contracts as Japanese/Korean did, and even fewer than overseas Chinese firms. This difference in long-term contracts may reflect the distinction between higher and lower level employees in Western and Japanese/Korean firms. It is the highly qualified employees that 
firms struggle to retain, and perhaps long-term contracts may be restricted to such employees in Western and Japanese/Korean firms. Offering long-term contracts to a broader group of employees may not be seen as useful for improving the retention of key employees.

However, our findings give us cause to re-consider the importance of long-term contracts for retaining employees of all levels. Long-term contracts may not be just a tool in themselves to retain employees. Instead, providing long-term contracts to a broader group of employees may be part of a company culture which signals the firm's long-term commitment to employees across all levels. Such a company culture may create more than merely contractual bonds. It may strengthen employees' psychological contracts and attachment to the firm and thereby enhance their tenure. Firms with such a culture are likely to use a set of interrelated HR practices which focus on long-term employee development and retention, that is, a long-term oriented HR system.

This speculation is supported by our finding that the HR practices that were associated with retention were also related to each other. The relationships between longterm contracts, contributions to pension funds, and attitudes towards pension funds followed a clear pattern, approaching linearity. The more one of these methods was present, the more the others would be used, as well. These HR practices may therefore all be part of an integrated HR system.

Researchers have previously stressed that integrated HR systems, which are also aligned with firm strategy, are important for succeeding in the Chinese context (e.g., Braun and Warner, 2002), e.g. in order to cope with low education levels (Zhu, Cooper, De Cieri, and Dowling, 2005). Our study suggests that such integrated HR systems are also crucial for retaining Chinese employees. Zhu et al. (2005) demonstrate that in 1994/5, and still in 2001, FIEs used strategically embedded HRM to a greater extent than Chinese firms did. 
However, they do not differentiate between the nationalities of the foreign firms they studied.

There are a number of reasons why Asian firms may use integrated, long-term oriented practices to a greater extent than do Western firms. On the one hand, the Western concept of 'high-performance' (Huselid, 1995, p.635) HR practices emphasises that a system of integrated, mutually reinforcing HR practices serves the retention of productive employees, and promotes the long-term performance of the firm in terms of sustained competitive advantage (Huselid, 1995). On the other hand, there may be historical and even cultural reasons why Asian firms deploy even more long-term oriented practices. Long-term employment contracts are likely to reflect the traditional institution of lifelong employment, which was until recently common in Japanese, Korean, as well as some overseas Chinese companies (Zhu et al., 2007). Long-term employment may also be tied to these countries' strong cultural value of LTO (Hofstede, 2003). In the same vein, the emphasis on social benefits, including pension funds, may be rooted in overseas Chinese firms' strong LTO, collectivism, and the Confucian value of mutual obligations between employer and employee.

However, variations in tenure are unlikely to be due to HR practices alone, given that only two of the examined HR practices were associated with both nationality and tenure. Culture may provide an additional explanation for variations in tenure between JVs of different nationality. As mentioned before, Chinese employees' relationships with their superiors seem to be important for their decision to stay with a company or leave. Due to cultural proximity, Chinese managers may be able to build stronger relations with their Chinese employees than Japanese or Western managers are. In particular, shared LTO and person-orientation may lead both parties to spend more time and effort in building long-term relationships ('guanxi') at work. Similar cultural meaning systems and a shared language 
can help avoid misunderstandings and strongly facilitate relations between managers and employees.

A number of unexpected results of this study must also be discussed. For example, we found that the percentage of expatriates and of local managers in a firm did not affect employee tenure. This is surprising, given the emphasis in previous research on the barriers for advancement of Chinese employees. A clue to this finding may lie in the lack of a relationship between the two variables. JVs that employed more expatriates did not necessarily employ fewer local employees. This was most apparent in Chinese-Western JVs, which counted high numbers of both expatriates and local managers. Therefore, the percentage of expatriates in total employees may not always reflect a lack of career chances for Chinese employees. Conversely, the number of local managers would not depend on the degree to which higher positions are filled with foreign staff. Western companies in our sample appeared to be building a local workforce and at the same time maintaining a high level of control through the expatriates. It is then easy to understand why the percentage of expatriates in total employees was not related to the other HR practices for retention. Employing more or fewer expatriates does not appear to be counterproductive for employee tenure, unless it is associated with a lower number of local managers. It is not in itself an HR practice for retention that would form part of a long-term oriented HR system.

Correspondingly, the percentage of local managers would not in itself be a practice for retention, but only if it was associated with fewer expatriates in the firms. Nevertheless, the percentage of local managers was related to a number of HR practices for retention, namely the contributions to pension funds, and bonus types. We could speculate that firms that employ a higher percentage of local managers may be aiming to localise their operations. They may therefore tend to adopt HR practices which are common in the local, Chinese context, such as high contributions to pension funds, regardless of the function for 
retaining employees. The relationship of local managers with bonus types, in contrast, was not linear. It may therefore be due to factors not captured in this investigation.

There are a few other, more puzzling findings. In line with our hypothesis 2 , participants who agreed that pension provision was the responsibility of the company worked in firms with higher employee tenure. Attitudes towards pension responsibility also related to actual contributions to pension fund, which differed between nationalities. Nevertheless, the views on pension responsibility did not vary with nationality. We reason that this finding may be due to factors outside the scope of the study

It was also contrary to our expectation that bonus types had a non-linear association with tenure and with the HR variables that were related to tenure. In particular, weekly/monthly bonuses were associated with higher scores on tenure, long-term contracts, contributions to pension funds, and pension responsibility than quarterly bonuses. This seems to contradict the idea of an integrated long-term oriented HR system. However, it is possible that the time intervals covered by our bonus measures were not large enough to distinguish between different degrees of LTO. The difference between monthly and quarterly bonuses may not be sufficient for encouraging employee tenure, and may for this reason not correspond to the use of other, retention-focused HR practices.

In relation to practitioners, our results demonstrate differences in employee tenure and in HR practices between JVs of different nationality in China. Moreover, the findings suggest that some of these HR practices are related to employee tenure, and that they could explain differences in employee tenure between JVs of different nationality.

This can be taken as a hint for Western HR managers to learn from Japanese and Korean firms, and for Western, Japanese and Korean managers to learn from overseas Chinese firms. Foremost, providing long-term contracts - preferably for all levels of employees - may be an important retention tool which Western MNEs in China presently 
use less than Japanese and Korean firms do, and even less than overseas Chinese firms. High contributions to employees' pension funds appear to be another effective retention method, which overseas Chinese firms apply to the greatest extent. Western MNEs in particular may be able to reduce their difficulties in retaining Chinese employees by benchmarking their HR practices against those of overseas Chinese, Korean, and Japanese firms.

There are a number of further lessons for MNEs who aim to build and retain a highly qualified workforce in China. Our findings suggest that HR practices are most effective if they are part of an integrated system of long-term oriented HR practices. We recommend that the HR system should be designed with the vision not simply to implement a range of retention tools, but, at a higher level, to create a culture of mutual commitment between employees and their firm, which in turn fosters strong psychological contracts. It is likely that such HR systems should contain many more HR practices than the ones examined in this study. MNEs are well advised to gain expertise regarding all options including, but also going beyond long-term contracts and pension funds.

Our findings contribute further towards the question how far MNEs should localise their management positions in China. From the point of view of employee retention, the numbers of local managers and expatriates do not seem to matter on their own. They may, however, matter in relation to each other. We suggest that high numbers of expatriates are not detrimental for Chinese employee retention as long as Chinese management careers are supported at the same time. Expatriates should be made fully aware of their responsibility to foster and not hinder Chinese managers' career paths.

Chinese managers may themselves play an important role in retaining other Chinese employees. Even if Western superiors earn respect based on their Western management style (Selmer, 1996), local Chinese managers are likely to benefit from their common 
cultural background and create stronger interpersonal bonds with their Chinese employees. These bonds could be crucial for creating stronger psychological contracts and increasing employee tenure.

\section{Conclusions}

This study was one of the first to show differences in tenure and HR practices for retention between firms of different nationality in China. The findings correspond to the research showing that Western and Asian firms use different HR practices (Farley et al., 2004; Rowley et al., 2004; Walsh and Zhu, 2007), and that there are differences in HRM between overseas Chinese and other Asian firms (Ngo et al., 1998). Our findings further implicate that some of these practices are relevant to increasing employee tenure, and may explain differences in employee tenure between JVs of different nationality. Therefore, Western, Japanese, and Korean firms may be well advised to benchmark their HR practices against those of overseas Chinese companies and thereby improve their own retention figures.

Further research is necessary to support our claims. Our enquiry focused only on a limited range of HR practices for retention. Insight into a wider range is needed in order to optimise a company's HR system. It is also necessary to examine HR systems in more depth, in order to understand the mechanisms by which they help achieve employee retention in China. It would be important to investigate how organisational commitment varies and affects tenure in firms of different nationality, and how it can be influenced through HR practices. Future research could also differentiate between employee skill levels and ages, to highlight how tenure of these different groups can be enhanced. Furthermore, one should explore other possible reasons for national differences in tenure, such as company language and relationships between local and foreign firm countries. Thus, there 
are many ways to carry this research forward, and this study provides a fruitful basis for such advances. 1

\footnotetext{
${ }^{1}$ Financial support from the Leverhulme Trust, grant number F/00 261/U, is
} gratefully acknowledged. 


\section{References}

Bjorkman, I. and Lu, Y. (2001) 'Institutionalization and bargaining power explanations of HRM Practices in International Joint Ventures - The case of Chinese-Western joint ventures', Organization Studies, 22(3): 491-512.

Bjorkman, I. and Xiucheng, F. (2002) 'Human resource management and the performance of Western firms in China', The International Journal of Human Resource Management, 13(6): $853-864$.

Braun, W. and Warner, M. (2002) Strategic human resource management in western multinationals in China. The differentiation of practices across different ownership forms, Personnel Review, 31(5): 553-579.

Chen, Z.X. and Francesco, A.M. (2000) 'Employee demography, organizational commitment, and turnover intentions in China: Do cultural differences matter?' Human Relations, 53(6): 869-887.

Chow, C.K., Fung, M.K., and Yue, N.H. (1999) 'Job turnover in China: A case study of Shanghai’s manufacturing enterprises', Industrial Relations, 38(4): 482-503.

Farley, J.U., Hoenig, S., and Yang, J.Z. (2004) 'Key Factors Influencing HRM practices of overseas subsidiaries in China's transition economy', The International Journal of Human Resource Management, 15(4/5): 688-704. 
Goodall, K. and Burgers, W. (1998) 'Frequent fliers', The China Business Review, MayJune: $50-52$.

Goodall, K. and Warner, M. (1997) 'Human Resources in Sino-Foreign Joint Ventures', The International Journal of Human Resource Management, 8(5): 569-94.

Hofstede, G. (2003) Cultures Consequences. Comparing Values, Behaviors, Institutions, and Organizations across Nations. London: Sage Publications.

Huselid, M. A. (1995) The impact of human resource management practices on turnover, productivity, and corporate financial performance, Academy of Management Journal, 38(3): 635-672.

Jackson, T. and Bak, M. (1998) 'Foreign companies and Chinese workers: employee motivation in the People's Republic of China', Journal of Organizational Change Management, 11(4): 282-300.

Legewie, J. (2002) 'Control and co-ordination of Japanese subsidiaries in China: problems of an expatriate-based management system', The International Journal of Human Resource Management, 13(6): 901-919.

Malila, J. (2007) 'The great look forward: China's HR Evolution', The China Business Review, July-August: 16-19. 
Melvin, S. (2001) 'Retaining Chinese Employees', The China Business Review, NovemberDecember: $30-43$.

Ngo, H.-Y., Turban, D., Lau, C.-M., and Lui, S.-Y. (1998) 'Human resource practices and firm performance of MNEs: influences of country origin', The International Journal of Human Resource Management, 9(4): 632-652.

Rein, S. (2007) 'How Multinationals Err in China.'

http://www.forbes.com/opinions/2007/05/24/china-glass-ceiling-oped-cx_sr_0524rein.html. Accessed 19 November 2007.

Rowley, C., Benson, J., and Warner, M. (2004) 'Towards an Asian model of human resource management? A comparative analysis of China, Japan and South Korea', The International Journal of Human Resource Management, 15(4): 917-933.

Selmer, J. (1996) 'Expatriate or local bosses? HCN subordinates' preferences in leadership behaviour', The International Journal of Human Resource Management, 7(1): 165-178.

Sheng, H. and Earsdon, M. (2007) 'Hewitt announces best employers in China 2007.' http://www.hewittassociates.com/Intl/AP/en-

November 2007. 
Sovic, N. (2006) 'Western firms find hiring, retention in China surprisingly tough.' The

Wall Street Journal Online: http://online.wsj.com/article/SB115523756653432470.html. Accessed 19 November 2007.

Speth, M. and Doeringer, C. (2006) 'Key talent retention in China.' http://www.hewittassociates.com/Lib/assets/AP/en-HT/pdfs/key_talent_retention.pdf. Accessed 19 November 2007.

Taura, R. (2005) 'Japanese Companies' HRM strategies in China', NRI Papers, 86, February 1: 1-10.

The China Business Review (2006) 'China's Tight Talent market.' http://www.chinabusinessreview.com/public/0603/ChinaData.pdf. Accessed 19 November 2007. Accessed 19 November 2007.

Walsh, J. and Zhu, Y. (2007) 'Local complexities and global uncertainties: a study of foreign ownership and human resource management in China', The International Journal of Human Resource Management, 18(2): 249-267.

Wang, Y.Y. (2004) 'Observations on the organizational commitment of Chinese employees: comparative studies of state-owned enterprises and foreign-invested enterprises', The International Journal of Human Resource Management, 15(4): 649-669.

Wang, Z. (1998) Japanese corporations’ investment in China. Beijing: Chinese Economic Press. 
Wilson, B. (2006) 'Companies in China struggling to retain staff, survey shows.' http://www.mercer.com/pressrelease/details.jhtml?idContent=1239885. $\quad$ Accessed 19 November 2007.

Zheng, C., Morrison, M., and O'Neill, G. (2006) 'An empirical study of high performance HRM practices in Chinese SMEs', The International Journal of Human Resource Management, 17(10): 1772-1803.

Zhu, C.J., Cooper, B., De Cieri, H., and Dowling, P.J. (2005) 'A problematic transition to a strategic role: human resource management in industrial enterprises in China', The International Journal of Human Resource Management, 16(4): 517-535.

Zhu, Y., Warner, M., and Rowley, C. (2007) 'Human resource management with 'Asian' characteristics: a hybrid people-management system in East Asia', The International Journal of Human Resource Management, 18(5): 745-768. 


\section{Figure 1}

\section{Research variables and examined relationships}

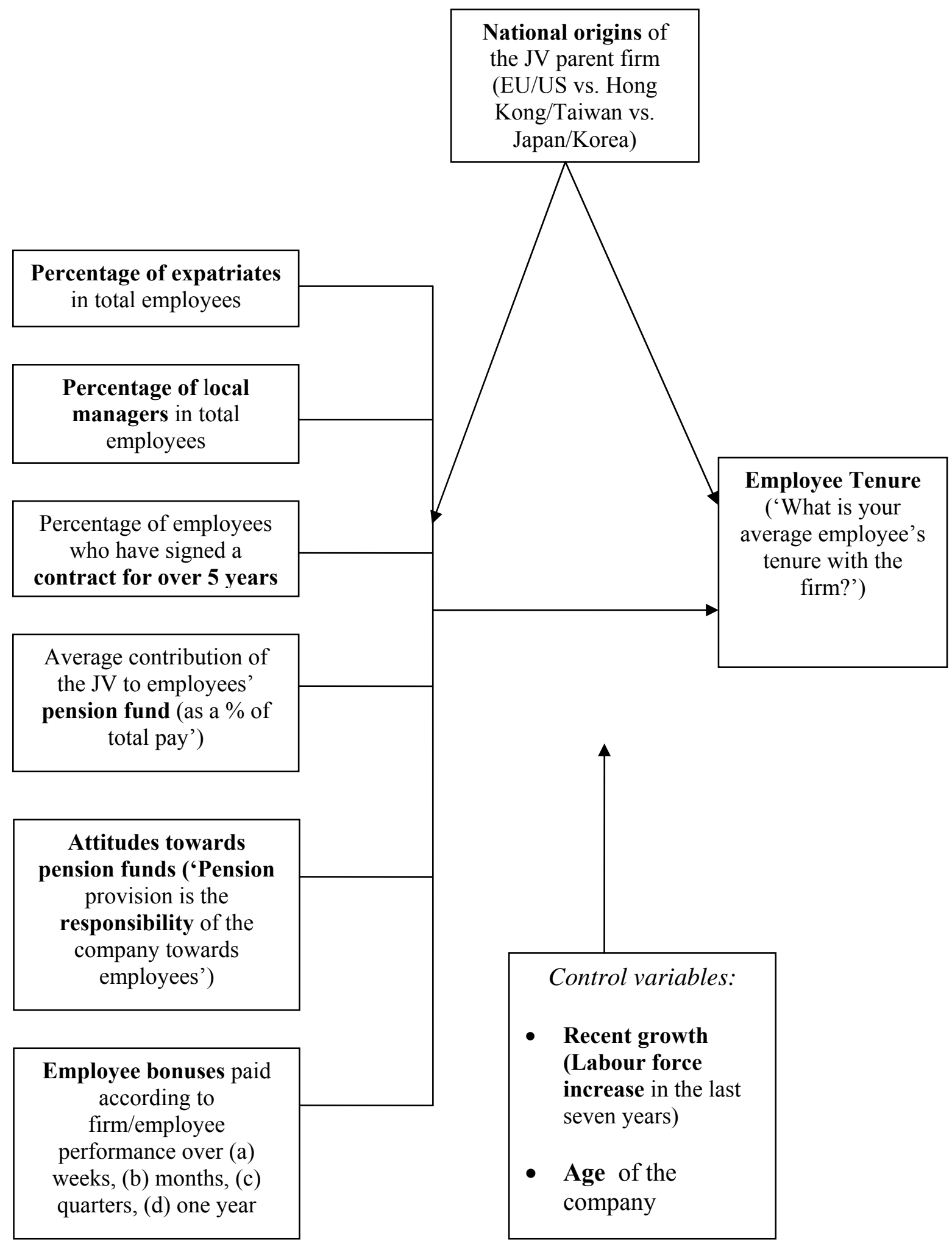


Table 1

Relationships of nationality and tenure with HR practices and control variables

\begin{tabular}{|c|c|c|}
\hline & & $\begin{array}{l}\text { National origins of the JV } \\
\text { parent firm (EU/US vs. Hong } \\
\text { Kong/Taiwan vs. } \\
\text { Japan/Korea) } \\
\end{array}$ \\
\hline & $\begin{array}{l}\text { Tenure ('What is your } \\
\text { average employee's tenure } \\
\text { with the firm?') }\end{array}$ & $\begin{array}{c}.031 * \\
(\chi 2) \\
\end{array}$ \\
\hline $\begin{array}{l}\text { 'The percentage of expatriates } \\
\text { in total employees' }\end{array}$ & $\begin{array}{c}.77 \\
(\text { ANOVA) }\end{array}$ & $\begin{array}{l}. \mathbf{0 0 0} * * * \\
(\mathrm{ANOVA})\end{array}$ \\
\hline $\begin{array}{l}\text { 'The percentage of local } \\
\text { managers in total employees' }\end{array}$ & $\begin{array}{c}.89 \\
\text { (ANOVA) }\end{array}$ & $\begin{array}{c}\mathbf{. 0 0 1 * *} \\
(\text { ANOVA) }\end{array}$ \\
\hline $\begin{array}{l}\text { 'What is the percentage of } \\
\text { employees who have signed a } \\
\text { contract for over } 5 \text { years?' }\end{array}$ & $\begin{array}{c}.000 * * * \\
(\chi 2)\end{array}$ & $\begin{array}{c}.006 * * \\
(\chi 2)\end{array}$ \\
\hline $\begin{array}{l}\text { Average contribution of the JV to } \\
\text { employees' pension fund (as a \% } \\
\text { of total pay') }\end{array}$ & $\begin{array}{c}.000 * * * \\
(\chi 2)\end{array}$ & $\begin{array}{l}.05+ \\
(\chi 2)\end{array}$ \\
\hline $\begin{array}{l}\text { 'Pension provision is the } \\
\text { responsibility of the company } \\
\text { towards employees' }\end{array}$ & $\begin{array}{c}.049 * \\
(\chi 2)\end{array}$ & $\begin{array}{l}.25 \\
\left(\chi^{2}\right)\end{array}$ \\
\hline $\begin{array}{l}\text { 'Are employee bonuses paid } \\
\text { according to firm/employee } \\
\text { performance over (a) weeks, (b) } \\
\text { months, (c) quarters, (d) one year' }\end{array}$ & $\begin{array}{c}.058+ \\
(\chi 2)\end{array}$ & $\begin{array}{l}.22 \\
(\chi 2)\end{array}$ \\
\hline $\begin{array}{l}\text { 'In any single year of the last } \\
\text { seven years, what was the largest } \\
\text { percentage of labour force } \\
\text { increase?' }\end{array}$ & $\begin{array}{l}.504 \\
(\chi 2)\end{array}$ & $\begin{array}{l}.177 \\
(\chi 2)\end{array}$ \\
\hline \begin{tabular}{|l} 
'How many years has the \\
company been established?'
\end{tabular} & $\begin{array}{l}. \mathbf{0 0 0} * * * \\
(\mathrm{ANOVA})\end{array}$ & $\begin{array}{c}.894 \\
(\text { ANOVA) }\end{array}$ \\
\hline
\end{tabular}

Note: $\mathrm{N}=316,{ }^{* * *} \mathrm{p}<.001 .{ }^{* *} \mathrm{p}<.01,{ }^{*} \mathrm{p}<.05,+\mathrm{p}<.10$. 
38

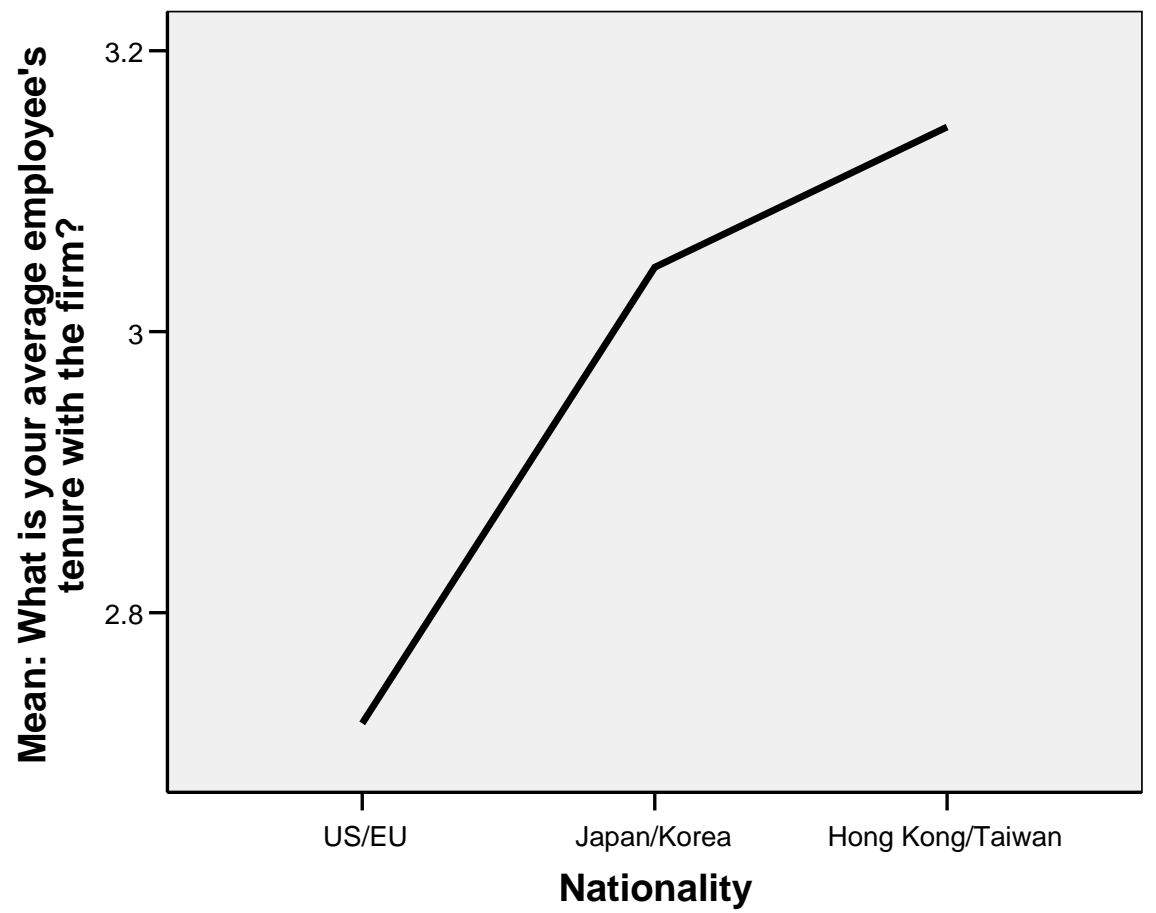

Figure 2

Nationality and tenure (a) 


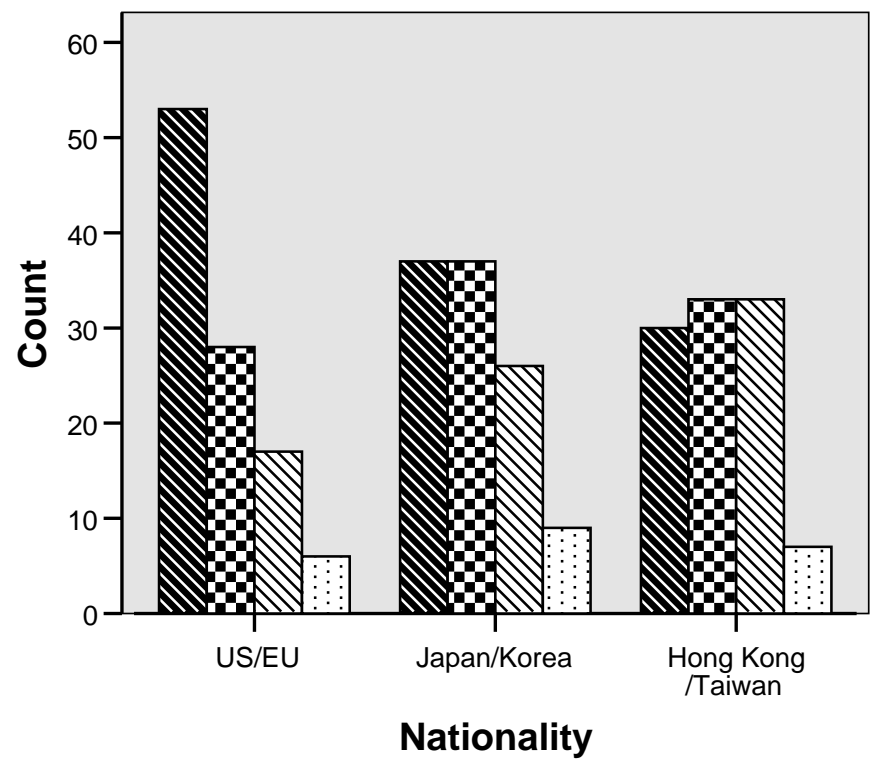

Tenure

0-3 years

4 4-5 years

6-10 years

: $>10$ years

Figure 3

Nationality and tenure (b) 
Table 2

Relationships between HR practices

\begin{tabular}{|c|c|c|c|c|c|c|}
\hline & $\begin{array}{l}\text { Percentage } \\
\text { of } \\
\text { expatriates }\end{array}$ & $\begin{array}{l}\text { Percentage } \\
\text { of local } \\
\text { managers }\end{array}$ & $\begin{array}{l}\text { Contract } \\
\text { for over } 5 \\
\text { years }\end{array}$ & $\begin{array}{l}\text { Contribution } \\
\text { to pension } \\
\text { fund }\end{array}$ & $\begin{array}{l}\text { Pension } \\
\text { responsibility }\end{array}$ & Type of bonus \\
\hline $\begin{array}{l}\text { Percentage of } \\
\text { expatriates }\end{array}$ & - & $\begin{array}{c}.12 \\
\text { (ANOVA) }\end{array}$ & $\begin{array}{c}.18 \\
\text { (ANOVA) }\end{array}$ & $\begin{array}{c}.19 \\
\text { (ANOVA) }\end{array}$ & $\begin{array}{c}.26 \\
\text { (ANOVA) }\end{array}$ & $\begin{array}{c}.37 \\
\text { (ANOVA) }\end{array}$ \\
\hline $\begin{array}{l}\text { Percentage of } \\
\text { local } \\
\text { managers }\end{array}$ & - & - & $\begin{array}{c}.84 \\
\text { (ANOVA) }\end{array}$ & $\begin{array}{c}\mathbf{. 0 0 8 * *} \\
(\text { ANOVA) }\end{array}$ & $\begin{array}{c}.204 \\
\text { (ANOVA) }\end{array}$ & $\begin{array}{c}\mathbf{. 0 5}+ \\
\text { (ANOVA) }\end{array}$ \\
\hline $\begin{array}{l}\text { Contract for } \\
\text { over } 5 \text { years }\end{array}$ & - & - & & $\begin{array}{c}.004 * * \\
(\chi 2)\end{array}$ & $\begin{array}{c}.017^{*} \\
(\chi 2)\end{array}$ & $\begin{array}{c}.025 * \\
(\chi 2)\end{array}$ \\
\hline $\begin{array}{l}\text { Contribution } \\
\text { to pension } \\
\text { fund }\end{array}$ & - & - & - & & $\begin{array}{c}.000 * * \\
(\chi 2)\end{array}$ & $\begin{array}{l}.019 * \\
(\chi 2) \\
\end{array}$ \\
\hline $\begin{array}{l}\text { Pension } \\
\text { responsibility }\end{array}$ & - & - & - & - & & $\begin{array}{c}.028 * \\
(\chi 2)\end{array}$ \\
\hline Type of bonus & - & - & - & - & - & \\
\hline
\end{tabular}

Note: $\mathrm{N}=316,{ }^{* * *} \mathrm{p}<.001 .{ }^{* *} \mathrm{p}<.01,{ }^{*} \mathrm{p}<.05,+\mathrm{p}<.10$.

...... Interrelation 